\title{
MANAGEMENT TRAINING INVENTORIES IN SMEE FOOD SECTOR (STUDY ON UMKM FOOD SECTOR IN TANGERANG CITY)
}

\author{
Indah Rahayu Lestari $^{1 *}$, Haryatih Haryatih ${ }^{1}$, Hestyaningsih Hestyaningsih ${ }^{1}$ \\ ${ }^{1}$ Departement of Accounting, Fakultas Ekonomi dan Bisnis, Budi Luhur University \\ *indahrahayu_lestari@outlook.com
}

\begin{abstract}
Based on survey and problem analysis faced by SMEs Food Field in Tangerang City in cooperation with Tangerang City Health Office, is problem of supply. MSME owners often experience excess stock in the warehouse for a particular product, or otherwise the lack of availability of goods that cause disruption of the production process. The causes of the deficiency or excess inventory include: 1) The amount of raw materials ordered only based on previous historical data and owners of MSMEs do not forecast sales and production, so it is not clear about the production plan and raw material needs plan that can be used as reference bookings materials, 2) the absence of safety stocks for each material used, causing the owners of MSMEs to lack or surplus inventory; 3 ) the absence of a clear inventory management system, in the absence of evidence of record keeping, valuation or inventory monitoring. So based on the analysis, the Dedication Team provides solutions in the form of knowledge management improvement for MSME owners in Tangerang City. Where in Community Service Training is held in the form of how to perform calculations, ranging from purchases, production to sales. Also provided training on product storage and efficient cost calculation in carrying out production. Community Service Activities on the training of inventory management and continued by training in making inventory cards using Microsoft Excel. Furthermore, will be provided assistance to SMEs for other fields such as making simple financial reports for MSMEs, computerized financial reports, as well as financial management and strategic management
\end{abstract}

Keywords: Inventory Management

\section{INTRODUCTION}

Inventory is a company's wealth, has an important role in business. In manufacturing, inventories can consist of: inventories of raw materials, auxiliary materials, work in process (WIP), finished goods and spare parts inventories. In an organization, such as food UMKM companies, most have supplies to be able to provide good service to customers. In a good company must be able to maintain the supply of raw materials, in order to carry out the production process smoothly, and the most important thing is to be able to meet consumer demand.In inventory management there are principal inventory stages contained in a production-distribution system from raw materials and ordering supplies through a productive process, which is reached at its peak so that it is available for use. In this system, we must first have raw materials and supplies in order to carry out the production process. If you want to be able to produce something with the least cost and according to the scheduled schedule, these items and supplies must be available. Therefore, policies must be made which determine when to complete this inventory and how much to order at a time.

The business increase volume from Micro, Small and Medium Enterprises (MSMEs), makes the MSME unit necessary to review its inventory strategy. One of the functions of inventory management is the planning of material needs, both raw material, packaging material, process materials, and finished goods. This function aims to plan how much and when the material is needed at the optimum cost level.These issues have to do with price cuts and because of the need for guarantees that delays in supply times and temporary increases in needs will not disrupt the operations that will be carried out.Supposedly with the raw material inventory policy implemented in the company, the 
inventory costs can be reduced as small as possible. To minimize inventory costs, an analysis of "Economic Order Quantity" (EOQ) can be used. EOQ is the most economical volume or number of purchases to be made at every time of purchase (Prawirosentono, 2001: 49). The EOQ method strives to achieve minimum inventory levels, lower costs and better quality. Planning EOQ method in the company will be able to minimize the occurrence of out of stock so that it does not interfere with the company's process and can save inventory costsissued by the company because of the efficiency of raw material inventory within the company. In addition, with the application of the company's EOQ method, it is able to reduce storage costs, save space, both for warehouse space and space

work, solve problems that arise from stacking inventory which reduces the risk that can arisebecause the inventory is in the warehouse.

To support this decision must be determined in advance the minimum amount of inventory in the warehouse and the reorder level of each material. This calculation requires accuracy because it is influenced by many factors including fluctuations in usage levels, fluctuations in procurement lead times and desired service levels. The existence of inventory has a strategic value for the company. Besides several advantages for the company, namely:

1. The company can meet the needs for the production process material precisely because of the availability of raw materials needed.

2. Used to guard against rising raw material prices that can affect the selling price

3. To anticipate shortages or scarcity of raw materials.

4. Availability of raw materials can fulfill the order appropriately.

5. Able to regulate the allocation of funds for various other needs.

Management of inventory management to run smoothly and in accordance with company plans must pay attention to the following:

1. There must be a basic inventory as a counterweight to the entry and exit of goods from the company. This means that there must be a large amount of inventory and it depends on whether or not the goods come in regularly or not.

2. The need to provide security inventory (safety stock). Because things are happening unexpectedly, there is a need to safeguard inventory (safety stock) to meet inventory needs when needed.

Anticipate inventory (anticipation stock), meaning that there is an need for additional inventories to anticipate future inventory growth. (Kasmir, 2010: 263)

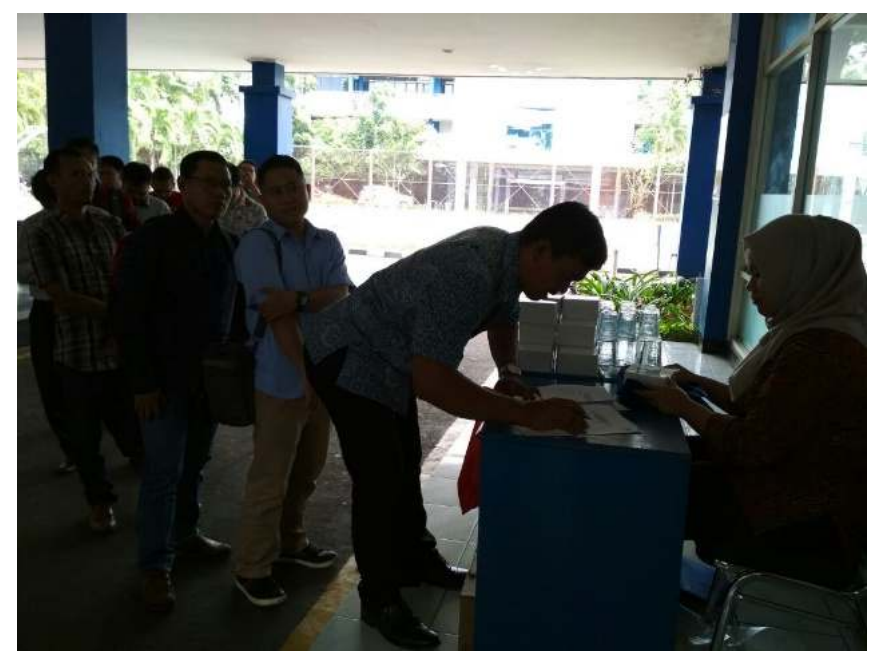

Figure 1. Participants Registration 


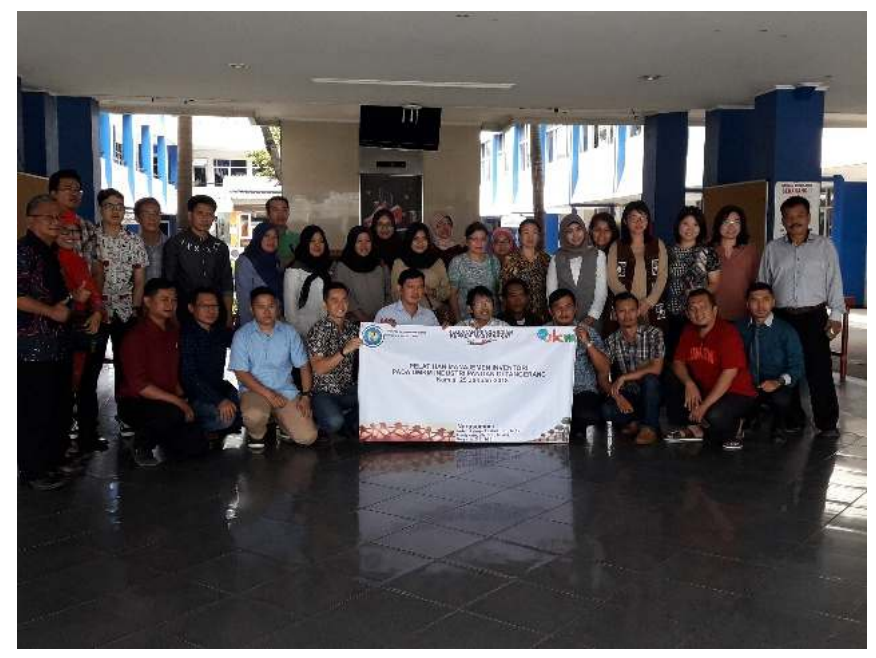

Figure 2. Training Participants

\section{Problem}

In producing or producing an item, of course it takes time, especially to order goods or raw materials. These goods or raw materials must be available when needed, therefore this time or period of ordering must be carefully calculated so as not to interfere with the production or sale of goods that consumers want. When ordering this, we are familiar with the Reorder Point (RoP). The formula that will be used for Reorder Points is as follows:(Kasmir, 2010:274)

$$
\mathrm{RoP}=\mathrm{Dh}+\mathrm{SS}
$$

Where is:

$\begin{array}{lll}\mathrm{RoP} & = & \text { Reorder Point } \\ \mathrm{Dh} & = & \text { Expected Request } \\ \mathrm{SS} & = & \text { During the grace period (lead time) }\end{array}$

This training will discuss management inventory and control inventory including training in applying methods to determine reorder levels and minimum stocks by considering these various factors.Participants will be given training in making inventory cards to MSME owners of food industry units. Training in the form of how to do calculations, ranging from purchases, production to sales. Also given training in product storage and efficient cost calculations in carrying out production. The development of MSMEs in the City of Tangerang according to the Head of Tangerang City Service H. Sayuti (published in Rakyat Merdeka Online 05 May 2018) states that the number of UMKM in Tangerang City in 2014 and 2015 was 10,079 units, an increase in 2016 and 2017 increased to as many as 10,432 units. Meanwhile, the number of UMKM in Tangerang City in 2016 was recorded at 10 thousand units. Then until the first quarter there were 10,553 units or 553 units of SMEs.

\section{Extensive Target}

Based on this condition, MSME owners often experience excess stock in warehouses for certain products, or vice versa, the lack of availability of goods that causes disruption of the production process. The causes of the shortage or excess inventory include: 1) The amount of raw material ordered is only based on previous historical data and the owner of the UMKM does not forecast sales and production, so it is not clear about the production plan and plan for raw material requirements that can be used as a reference order material, 2) lack of safety stock for each material used, causing MSME owners to lack or overstock inventory, 3) lack of a clear inventory management system, with no evidence of inventory recording, valuation or supervision. 


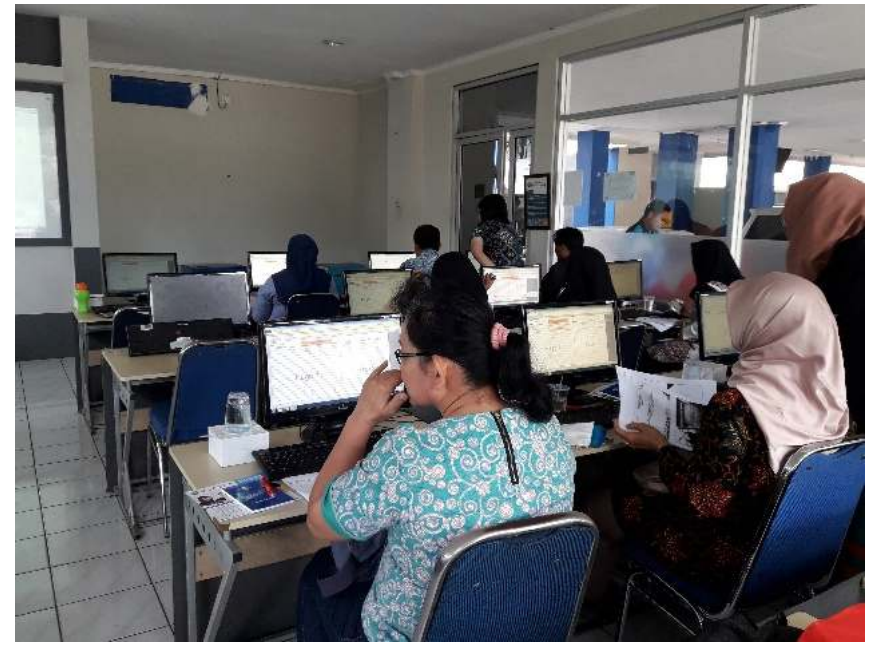

Figure 3. Inventory Management Inventory

\section{METHOD}

Prior to service, correspondents and discussions were conducted with the Health Office. The Health Service in this case is the body that oversees the UMKM in the food sector. The service team held discussions to find out the needs of MSMEs. Based on the results of the discussions and surveys conducted, MSMEs have difficulty in recording, calculating and supplying supplies. The method used in this service is counseling, training, and evaluation of the training that has been carried out. With the following dedication stages:

1) counseling to increase knowledge about what is inventory management, and how important inventory recording is in a production company.

2) Training phase regarding product storage and efficient cost calculation in carrying out production.

3) Determination of Safety Supplies, which is very necessary to support the smoothness of raw material shortages which will result in the process stopping and employees not working.

4) Determination of Re Order Points by calculating in advance the level of use of raw materials per day.

Community Service Activities concerning inventory management training and continued with training in creating inventory cards using Microsoft Excel.

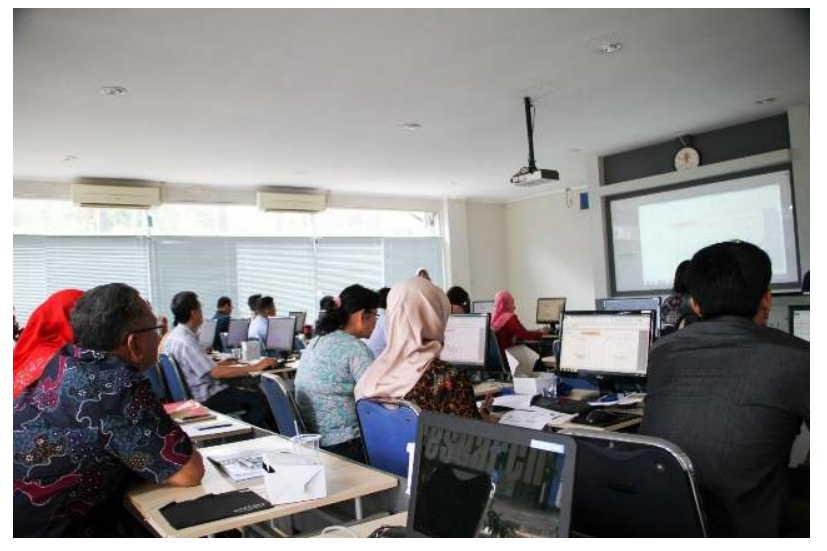

Figure 4. Inventory Card Training 


\section{RESULT AND DISCUSSION}

All planned service activities have been carried out smoothly. Where this service activity is divided into 2 (two), where the first stage is an extension activity to increase knowledge about the importance of inventory recording, while in the second stage is training in inventory recording and calculation.

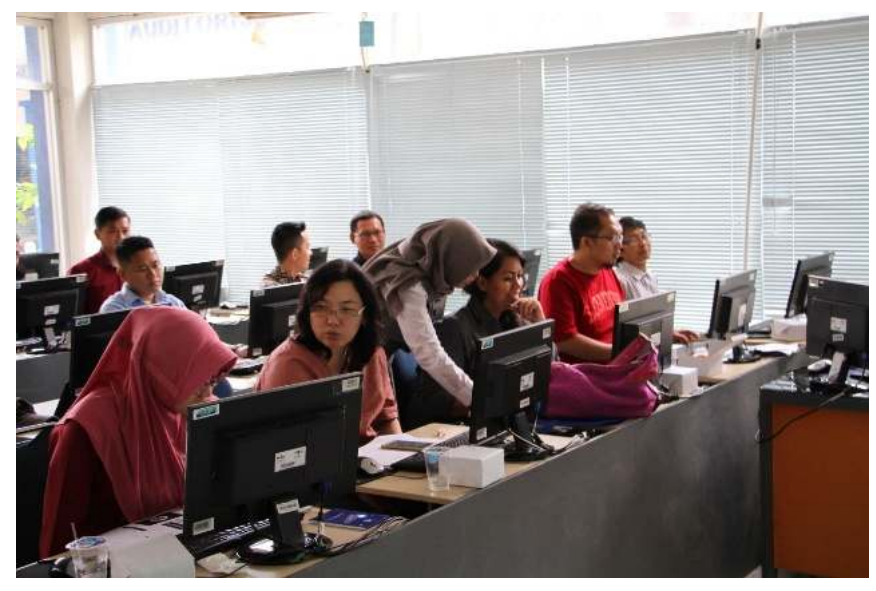

Figure 5. Checking Participants Activities

\section{CONCLUSION}

\section{Conclusion}

From the activities that have been carried out, it is concluded that there are 2 (two) stages of the service activities that have been carried out. Activities have been carried out well, even the UMKM participants who attended exceeded the quota of participants provided. MSME partners are active in every stage of the activities carried out. With this activity also increases the knowledge and understanding of MSME owners regarding the importance of good inventory recording and management. Where previously to find out the inventory of goods only based on the physical goods available in the warehouse. So that there is often excess stock, or vice versa the lack of availability of goods that causes disruption of the production process.

\section{Suggestion}

Based on the above conclusions, it can then be proposed to go to the next stage. Applying Re Order Points is expected to be more efficient in spending inventory costs, providing a safety stock that amounts to the amount produced. This can also anticipate shortages or excess stock of raw materials that cause disruption of the production process.Furthermore, assistance will be made to MSMEs in other fields such as making simple financial reports for MSMEs, computerized financial reports, and financial management and strategic management. Furthermore, UMKM must carry out neat and orderly records, so that they can carry out inventory management to the maximum.It is necessary to have a regular record of inventory from the start of goods, production, finished goods, to sales.

\section{REFERENCES}

Indonesia, R. (2004). Peraturan Pemerintah No. 28 Tahun 2004 tentang Keamanan, Mutu dan Gizi Pangan. Sekretariat Negara. Jakarta.

Kasmir.(2010). Pengantar Manajemen Keuangan .Edisi Kedua. Jakarta. Kencana. 
Prawirosentono, S. (2001).Manajemen Operasi Analisis dan Studi Kasus. Bumi Aksara, Jakarta.

Rakyat Merdeka Online. (2018). Pemkot Tangerang Dorong Pertumbuhan UMKM Berkualitas. Sabtu 05 Mei 2018.

Weygandt, Kimmel, Kieso. 2013.Financial Accounting, IFRS Edition: 2e. Cita. 